\title{
The evolution of sustainable development in Public International Law
}

\author{
Citation for published version (APA):
}

Kristy, M. A. C. (2021). The evolution of sustainable development in Public International Law: how does it inform the application and interpretation of WTO Agreements covering the domestic regulation of trade in goods? [Doctoral Thesis, Maastricht University]. Maastricht University. https://doi.org/10.26481/dis.20210429mk

Document status and date:

Published: 01/01/2021

DOI:

10.26481/dis.20210429mk

Document Version:

Publisher's PDF, also known as Version of record

\section{Please check the document version of this publication:}

- A submitted manuscript is the version of the article upon submission and before peer-review. There can be important differences between the submitted version and the official published version of record.

People interested in the research are advised to contact the author for the final version of the publication, or visit the DOI to the publisher's website.

- The final author version and the galley proof are versions of the publication after peer review.

- The final published version features the final layout of the paper including the volume, issue and page numbers.

Link to publication

\footnotetext{
General rights rights.

- You may freely distribute the URL identifying the publication in the public portal. please follow below link for the End User Agreement:

www.umlib.nl/taverne-license

Take down policy

If you believe that this document breaches copyright please contact us at:

repository@maastrichtuniversity.nl

providing details and we will investigate your claim.
}

Copyright and moral rights for the publications made accessible in the public portal are retained by the authors and/or other copyright owners and it is a condition of accessing publications that users recognise and abide by the legal requirements associated with these

- Users may download and print one copy of any publication from the public portal for the purpose of private study or research.

- You may not further distribute the material or use it for any profit-making activity or commercial gain

If the publication is distributed under the terms of Article $25 \mathrm{fa}$ of the Dutch Copyright Act, indicated by the "Taverne" license above, 


\section{SUMMARY}

The Evolution of Sustainable Development in Public International Law: How Does It Inform the Application and Interpretation of WTO Agreements Covering the Domestic Regulation of Trade in Goods?

In 2015, the concept of sustainable development was put at the heart of the global development agenda: "Transforming our World: the 2030 Agenda for Sustainable Development". The concept of sustainable development was substantively developed in both the Brundtland Report in 1987 and the Rio Declaration in 1992 and reflected the recognition that economic development cannot be pursued without consideration of the need to protect the environment. This dissertation explores the implications of the evolution of the concept of sustainable development in public international law for the WTO agreements covering the domestic regulation of trade in goods.

The first part of this dissertation assesses the evolution of the concept of sustainable development in public international law. The legal status of the concept of sustainable development in public international law has not yet crystallized. Legal scholars and the decisions of international tribunals have taken different views on the legal status of "sustainable development" in public international law. Despite the contentious debates on the legal status of the concept of sustainable development, international tribunals have so far been hesitant to clarify the legal nature and status of the concept of sustainable development.

This thesis argues that the legal nature of the concept of sustainable development is a legal principle. The concept of sustainable development is not only a norm but a legal norm with normative weight. This thesis analyses that the principle of sustainable development can perform a collective identity function and a decision-making function. The database on the reference to "sustainable development" in international treaties and the decisions of international tribunals indicates a common normative character operationalizing the principle of sustainable development, i.e. a duty to protect the environment and rights of economic and social development.

Related to the legal status of sustainable development, this thesis argues that the principle of "sustainable development" is a general principle of international law identified as one of the sources of international law stated in Article 38(1) ICJ Statute. A principle has to be common to most legal systems of the world or can be generalized from an inductive reference to uniform State practice, reflected in treaties or customary international law, to be qualified as 
a general principle of law recognized by civilized nations. The GA Resolution A/RES/70/1 reflects the recognition and commitment of UN Member States with regard to sustainable development. Having "sustainable development" referred to in the GA Resolution helps generate a widespread State practice among UN Member States. As a general principle of law recognized by civilized nations, the principle of sustainable development could have a normative effect as relevant international law in the context of treaty interpretation (with or without explicitly being mentioned in the text of a treaty). This thesis introduced the six components of the principle of sustainable development, which are: the component of integration, the component of sustainable use; the component of equity (intra-generation and inter-generation); special and differential treatment component; the component of public participation, transparency, data access, and information; the precautionary approach component. Looking at the principle of sustainable development into six components allows for a more comprehensive analysis as compared to an approach based only on the integration of the environmental, economic and social dimensions per se.

The second part of this dissertation analyses how the components of the principle of sustainable development find their reflection and how the status of the term "sustainable development" as one of the WTO objectives could influence the interpretation of provisions covering domestic regulation in the GATT 1994, the TBT Agreement and the SPS Agreement. The analysis of the second part also attempts to respond to how the WTO panels and Appellate Body have referred to "sustainable development" as one of the WTO objectives in interpreting certain provisions in the WTO agreements covering the domestic regulation of trade in goods.

The multilateral trading system plays a significant role in operationalizing the principle of sustainable development. Unlike the GATT 1947, the term "sustainable development" is explicitly mentioned in the Preamble of the Marrakesh Agreement as one of the WTO objectives. The term "sustainable development", as one of the WTO objectives, sheds light on the intentions of the negotiators of the Marrakesh Agreement and adds colour, texture and shading to the interpretation of the provisions of the WTO agreements. In the Uruguay Round, the principle of sustainable development was initially construed by taking into consideration environmental issues and special and differential treatment provisions. As part of the evolution of "sustainable development", the scope of the principle of sustainable development has broadened from an initial focus on environmental protection to also include a social dimension.

The analysis in this dissertation finds that the provisions of the GATT 1994, TBT Agreement and SPS Agreement covering the domestic regulation of trade in goods allow WTO 
Members to apply the principle of sustainable development. The six components of the principle of sustainable development help map the reflection of the principle of sustainable development in the policy sphere of the WTO.

WTO panels and the Appellate Body play important roles in fostering the principle of sustainable development in the rules of the multilateral trading system through their interpretation of WTO provisions. The inclusion of "sustainable development" as a WTO objective allows panels and the Appellate Body to argue that referring to "sustainable development" in their interpretation is aligned with the objectives of the WTO. "Sustainable development" as one of the WTO objectives was referred to the interpretation of "natural resources" in Article XX(g) by the Appellate Body in US - Shrimp and "products in general or local short supply" in Article XX(j) by the Appellate Body in India-Certain Measures Relating to Solar Cells and Solar Modules. WTO panels and the Appellate Body have not sufficiently exploited the reference to "sustainable development" in their interpretation of WTO agreements covering the domestic regulation of trade in goods. Exploiting the reference to "sustainable development" as a WTO objective would help WTO panels and the Appellate Body interpret certain terms beyond the current interpretation and would strengthen the operationalization of the principle of sustainable development in WTO agreements.

Building on the findings from the analysis, the reflection of the six components of the principle of sustainable development in the GATT 1994, the TBT Agreement and the SPS Agreement reveals opportunities to better integrate the principle of sustainable development into the reading and interpretation of the WTO agreements. As one of the WTO objectives, WTO panels and, as long as the Appellate Body is paralysed, MPIA arbitrators have to exploit the reference to "sustainable development" better in interpreting certain terms in the WTO agreements. 